\title{
First records of the occurrence of twelve species of Sabethini (Diptera, Culicidae) in the state of Paraná, southern Brazil
}

\author{
Allan Martins da Silva ${ }^{1}$, Demilson Rodrigues dos Santos ${ }^{2}$, Edilson Colhera Cristóvão ${ }^{2}$, \\ Adão Celestino Ferreira ${ }^{2}$, Claudomiro Postai ${ }^{2}$, Betina Westphal-Ferreira ${ }^{3}$, \\ Mário Antônio Navarro da Silva ${ }^{3}$
}

1 Secretaria de Estado da Saúde do Paraná, Laboratório Central, Seção de Entomologia, Rua Sebastiana Santana Fraga, 1001, CEP 83060-500, São José dos Pinhais, PR, Brazil. 2 Secretaria de Estado da Saúde do Paraná, Superintendência de Vigilância em Saúde, Departamento de Vigilância Ambiental, Rua Piquiri, 170, CEP 83230-140, Curitiba, PR, Brazil. 3 Universidade Federal do Paraná, Setor de Ciências Biológicas, Departamento de Zoologia, Caixa Postal 19020, 81531-980, Curitiba, PR, Brazil.

Corresponding author: Allan Martins da Silva, allan.silva@sesa.pr.gov.br

\begin{abstract}
We report on the first records of Sabethini mosquitoes in the state of Paraná, based on specimens collected in forested environments between 2004 and 2005. In total, 12 species were identified, including 7 species of Wyeomyia Theobald, 1901 and 5 species of Sabethes Robineau-Desvoidy, 1827. Among them, 6 are new records for the southern region of the country, and 6 are new records for the state of Paraná. These results indicate the occurrence of relict species of mosquitoes in Paraná, as they were collected from portions of forests that preserve original characteristics.
\end{abstract}

\section{Key words}

Diversity, geographic distribution, Sabethini, tropical forest. occurrence of twelve species of Sabethini (Diptera, Culicidae) in the state of Paraná, southern Brazil. Check List 15 (1): 193-201. https://doi. org $/ 10.15560 / 15.1 .193$

\section{Introduction}

Sabethini (Diptera, Culicidae) are diurnal mosquitoes found both in forested environments and next to anthropic areas. These mosquitoes occur in various regions of the world but are most abundant in tropical and subtropical climates where high amounts of rainfall favor the formation of aquatic micro-ecosystems known as phytotelmata. Sabethini females lay eggs on phytotelmata and the immature forms of this mosquito develop there (Forattini 2002).

In the Americas there are 9 genera of Sabethini in about 221 species, mostly found in tropical climates: Isostomyia,
Johnbelkinia, Limatus, Phoniomyia, Runchomyia, Sabethes, Shannoniana, Trichoprosopon and Wyeomyia. There, the primitive plant formations, climate and soil type determine the distribution and occurrence of mosquitoes. In Brazil, large areas of equatorial, tropical and temperate climate and vegetation have allowed many species of Sabethini to thrive (Lane and Cerqueira 1942, Harbach et al. 2007).

However, since European colonization there have been changes in the original vegetation of the Americas caused by land use and other human activities. For instance, the destruction of forests in the state of Paraná, Brazil, started in 1820 with the cultivation of the yerba 
mate. The original biota of the Atlantic Forest, including mangroves and salt marshes, and which covered $84 \%$ of the state's surface, today represents less than $8 \%$ of the area. The Atlantic Forest is currently reduced to disjointed spots, most of them constituting formations secondary stages in different successional stages (Maack 1981, Kronen 1990, Morellato and Haddad 2000).

Studies on the fauna of mosquitoes in regions of Paraná that have remaining forests have demonstrated the existence of populations of Sabethini (Bona and NavarroSilva 2008, Tissot and Navarro-Silva 2008, Muller at al. 2008, 2012, Guedes and Navarro-Silva 2014). In this study, we report new records from protected and residual forests in the state.

\section{Methods}

The study area is within the state of Paraná, which is located in southern Brazil Entomological surveys were conducted between 2004 and 2005 in the forested areas of 18 localities, distributed in 20 municipalities ( 2 points are in contiguous municipalities), represented by environmental preservation areas and private properties, with the presence of residual forests (Table 1; Fig. 1).

Females of Sabethini were collected inside the forest using the human attraction technique. The mosquitoes were captured using a tube containing Chloroform and by hand nets. Ground-level samples were collected over a transect with 18 focal points separated by $10 \mathrm{~m}$. Each central point was positioned about $30 \mathrm{~m}$ from a tree in the forest canopy selected for collection. The collector

Table 1. Geographical coordinates of the field stations where insect collecting took place in the forested areas of Paraná, between April, 2004 to June 2006

\begin{tabular}{|c|c|c|}
\hline RS* & Municipality & Coordinates \\
\hline \multicolumn{3}{|c|}{ Dense Ombrophilous Forest } \\
\hline & Paranaguá & $25^{\circ} 54^{\prime} 44.9^{\prime \prime} \mathrm{S}, 048^{\circ} 56^{\prime} 31.2^{\prime \prime} \mathrm{W}$ \\
\hline & Matinhos & $26^{\circ} 25^{\prime} 24.5^{\prime \prime} \mathrm{S}, 048^{\circ} 57^{\prime} 28.7^{\prime \prime} \mathrm{W}$ \\
\hline & Guaraqueçaba & $25^{\circ} 18^{\prime} 22.4^{\prime \prime} \mathrm{S}, 048^{\circ} 43^{\prime} 15.1^{\prime \prime} \mathrm{W}$ \\
\hline \multicolumn{3}{|c|}{ Mixed Ombrophilous Forest } \\
\hline & Piên & $26^{\circ} 10^{\prime} 40.4^{\prime \prime} \mathrm{S}, 049^{\circ} 42^{\prime} 26.9^{\prime \prime} \mathrm{W}$ \\
\hline & Prudentópolis & $24^{\circ} 48^{\prime} 00.0^{\prime \prime} \mathrm{S}, 051^{\circ} 14^{\prime} 00.0^{\prime \prime} \mathrm{W}$ \\
\hline & Mariópolis & $26^{\circ} 16^{\prime} 08.0^{\prime \prime} \mathrm{S}, 052^{\circ} 33^{\prime} 53.0^{\prime \prime} \mathrm{W}$ \\
\hline \multicolumn{3}{|c|}{ Fields (Campo Geral and Cerrado) } \\
\hline & Jaguariaíva & $24^{\circ} 22^{\prime} 43.6^{\prime \prime} \mathrm{S}, 049^{\circ} 39^{\prime} 38.0^{\prime \prime} \mathrm{W}$ \\
\hline \multicolumn{3}{|c|}{ Seasonal Semideciduous Forest } \\
\hline & $\begin{array}{l}\text { Carlópolis and } \\
\text { Joaquim Távora }\end{array}$ & $23^{\circ} 15^{\prime} 24.1^{\prime \prime} \mathrm{S}, 050^{\circ} 57^{\prime} 55.9^{\prime \prime} \mathrm{W}$ \\
\hline & Tomazina & $23^{\circ} 50^{\prime} 57.9^{\prime \prime} \mathrm{S}, 049^{\circ} 57^{\prime} 36.1^{\prime \prime} \mathrm{W}$ \\
\hline & Três Barras do Paraná & $25^{\circ} 26^{\prime} 22.0^{\prime \prime} \mathrm{S}, 053^{\circ} 09^{\prime} 34.0^{\prime \prime} \mathrm{W}$ \\
\hline & Foz do Iguaçu & $25^{\circ} 36^{\prime} 26.0^{\prime \prime} \mathrm{S}, 054^{\circ} 26^{\prime} 50.0^{\prime \prime} \mathrm{W}$ \\
\hline & Terra Roxa & $23^{\circ} 03^{\prime} 18.8^{\prime \prime} \mathrm{S}, 054^{\circ} 08^{\prime} 03.7^{\prime \prime} \mathrm{W}$ \\
\hline & $\begin{array}{l}\text { Cornélio Procópio and } \\
\text { Santa Mariana }\end{array}$ & $23^{\circ} 09^{\prime} 03.4^{\prime \prime} \mathrm{S}, 050^{\circ} 34^{\prime} 17.8^{\prime \prime} \mathrm{W}$ \\
\hline & Assaí & $23^{\circ} 22^{\prime} 01.9^{\prime \prime} \mathrm{S}, 050^{\circ} 49^{\prime} 32.8^{\prime \prime} \mathrm{W}$ \\
\hline & Maringá & $23^{\circ} 43^{\prime} 00.6^{\prime \prime} \mathrm{S}, 052^{\circ} 33^{\prime} 11.8^{\prime \prime} \mathrm{W}$ \\
\hline & Inajá & $22^{\circ} 39^{\prime} 25.8^{\prime \prime} \mathrm{S}, 052^{\circ} 15^{\prime} 15.8^{\prime \prime} \mathrm{W}$ \\
\hline & Porto Rico & $23^{\circ} 15^{\prime} 26.4^{\prime \prime} \mathrm{S}, 053^{\circ} 28^{\prime} 10.7^{\prime \prime} \mathrm{W}$ \\
\hline & Cianorte & $24^{\circ} 08^{\prime} 13.9^{\prime \prime} \mathrm{S}, 053^{\circ} 00^{\prime} 52.9^{\prime \prime} \mathrm{W}$ \\
\hline
\end{tabular}

remained for $20 \mathrm{~min}$ at each focal point. Collections in the tree tops were made between $10 \mathrm{~m}$ and $15 \mathrm{~m}$ from the ground and considered the average height of the dominant trees at each site. To collect in the canopy, various types of platforms were accessed through rope ladders and pulleys.

For each species, we give the known distribution in the Americas and the new records. detailing the collection site: geographical coordinates and altitude above (mean) sea level (a.s.1); data collection by human attraction (col.), date of collection; researched forest stratum (CO $=$ Canopy, Soil $=\mathrm{SO}$ ); and time interval and the number of specimens collected. The information is supplemented with the species' bionomic data and the specimen number in the entomological collection (DZUP).

Specimens were identified with the help of dichotomous keys by Lane (1953) and Forattini (2002), and the literature describing species of Sabethini. Dr Maria Anice Mureb Sallum (Faculdade de Saúde Pública, Universidade de São Paulo) confirmed our identifications. Voucher materials were deposited in the Padre Jesus Santiago Moure Entomological Collection (Diptera), Departamento de Zoologia, Universidade Federal do Paraná (DZUP).

Knowledge of the distribution of Sabethini in the Americas was obtained from Navarro et al (2015), and

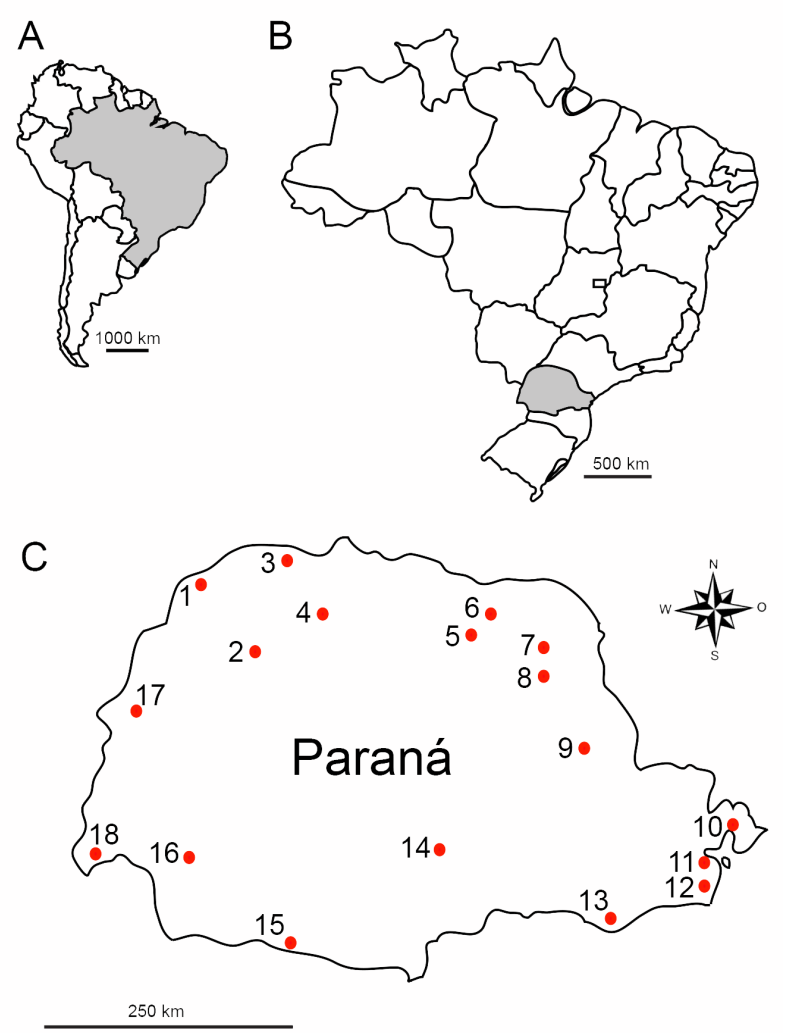

Figure 1. A. Location of Brazil in South America. B. Location of the state of Paraná in Brazil. C. Distribution of municipalities in the state of Paraná, with record of the first occurrence of mosquitoes. Legend: 1. Porto Rico, 2. Cianorte, 3. Inajá, 4. Maringá, 5. Assaí, 6. Cornélio Procópio and Santa Mariana, 7. Carlópolis and Joaquim Távora, 8. Tomazina, 9. Jaguariaíva, 10. Guaraqueçaba, 11. Paranaguá, 12. Matinhos, 13. Piên, 14. Prudentópolis, 15. Mariópolis, 16. Três Barras do Paraná, 17. Terra Roxa, 18. Foz do Iguaçu. 
the Walter Reed Biosystematics Unit (2017) online catalog. To check the originality of the species records in southern Brazil and Paraná, we consulted Lane and Cerqueira (1942), and the lists of entomological collections presented by Marchon-Silva et al. (1996), Hutchings et al. (2005), and Tissot and Navarro-Silva (2008). In addition, the lists compiled by Cardoso et al. $(2005,2010)$ for Rio Grande do Sul and Müller et al. (2008) for Paraná and Santa Catarina were also consulted. The distribution of mosquito species is presented based on the main natural characteristics of Paraná, according to the Maack (1981) and Wons (1985).

The review of articles published after the lists mentioned above include: for Rio Grande do Sul: Gomes et al. (2010); for Paraná: Anjos and Navarro-Silva (2008), Bona and Navarro-Silva (2008), Tissot and Navarro-Silva (2008), Marchi et al. (2010), Müller et al. (2012), Guedes and Navarro-Silva (2014) and Lopes et al. (2014); and for Santa Catarina: Gomes et al. (2009), Reis et al. (2010), Favretto et al. (2013), Müller et al. (2014), Santos et al. (2014) and Ferreira-de-Freitas et al. (2016).

The nomenclature and taxonomic classification of the Sabethini follows Motta et al. (2007) and Harbach (2018). The abbreviation of genera and subgenera follow Reinert (2009).

\section{Results}

The identification of Sabethini mosquitoes collected in forested environments of Paraná, based on the morphological characteristics of the female, resulted in 12 new records, including 7 species of Wyeomyia Theobald, 1901, and 5 species of Sabethes Robineau-Desvoidy, 1827. Among them, 6 are new records for southern Brazil, and 6 are new records for Paraná.

\section{First records for southern Brazil}

\section{Sabethes (Sabethes) shannoni Cerqueira, 1961}

Figures 2A, 3A-C

\section{Distribution. Brazil.}

New records. Brazil: Paraná: Cornélio Procópio, Parque Estadual Mata São Francisco $\left(23^{\circ} 09^{\prime} 03^{\prime \prime} 0\right.$ S, 050³4' 17"W, 553 m a.s.1.); coll. 09.VIII.2004, SO 12h40-13h00, 1 ㅇ (voucher DZUP 180506).

Bionomic data. This species occurs in the Terceiro Planalto Paranaense and is found in preserved forest with original characteristics, which is in the small basin of the Paranapanema River. The region has an annual average air temperature of $21-22{ }^{\circ} \mathrm{C}$ and average rainfall of $1,600-1,800 \mathrm{~mm}$ annually.

Identification. Sa. (Sab.) shannoni differs from Sa. (Sab.) tarsopus Dyar \& Knab, 1908, Sa. (Sab.) ortizi Vargas \& Nájera, 1961 and Sa. (Sab.) belisaroi Neiva, 1908 by the extension of the white scale spots at the fore- and midtarsus. Sa. (Sab.) shannoni foretarsus is covered by white
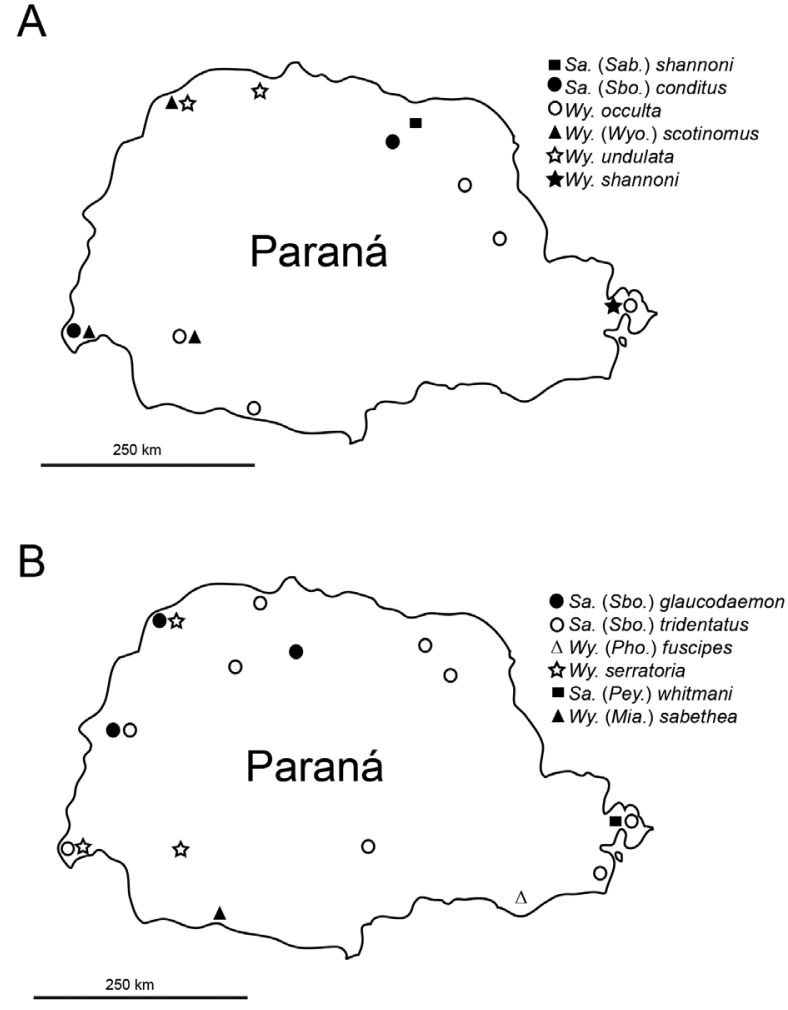

Figure 2. Location of the first records of the species in the state of Paraná, Brazil. A. First records for Southern Brazil. B. First records for the state of Paraná.

scales from the apex of the tarsomere (Ta) II to the base of Ta-IV (Fig. 3B) and the midtarsus has white scales on the base of Ta-II to the apex of Ta-IV (Fig. 3C).

\section{Sabethes (Sabethoides) conditus Moses, Howard \& Harbach, 2000}

Figures 2A, 3D-G

Distribution. Brazil, Venezuela.

New records. Brazil: Paraná: Assaí, Cooperativa Algodoeira $\left(23^{\circ} 43^{\prime} 00^{\prime \prime} \mathrm{S}, 050^{\circ} 50^{\prime} 15^{\prime \prime} \mathrm{W}, 630 \mathrm{~m}\right.$ a.s.1.); coll. 18.I.2005, SO 12h40-13h00, 19 (DZUP 180505). Bra-

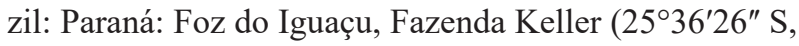
$054^{\circ} 28^{\prime} 48^{\prime \prime} \mathrm{W}, 228 \mathrm{~m}$ a.s.1.); coll. 15.III.2004, CO 17h0018h00, 1 (DZUP249686).

Bionomic data. The species was collected in the Terceiro Planalto Paranaense in secondary riparian forest of the Tibagi River, near the mouth of the Iguaçu River. In the tropical zone area, the annual average air temperature ranges between $21^{\circ} \mathrm{C}$ and $22^{\circ} \mathrm{C}$, while in the subtropical zone areas, the average annual air temperature varies between $19{ }^{\circ} \mathrm{C}$ and $21{ }^{\circ} \mathrm{C}$. The average rainfall ranges from $1,600 \mathrm{~mm}$ to $1,800 \mathrm{~mm}$ annually.

Identification. $\mathrm{Sa}$. (Sbo.) conditus is similar to $\mathrm{Sa}$. (Sbo.) chloropterus (Humboldt, 1819), Sa. (Sbo.) tridentatus Cerqueira, 1961 and Sa. (Sbo.) glaucodaemon (Dyar \& Shannon, 1925), but differs by the ociput with goldengreen scales (Fig. 3E), short upper mesepimeral setae reaching the mesopostnotum (Fig. 3F) and the midtarsus 

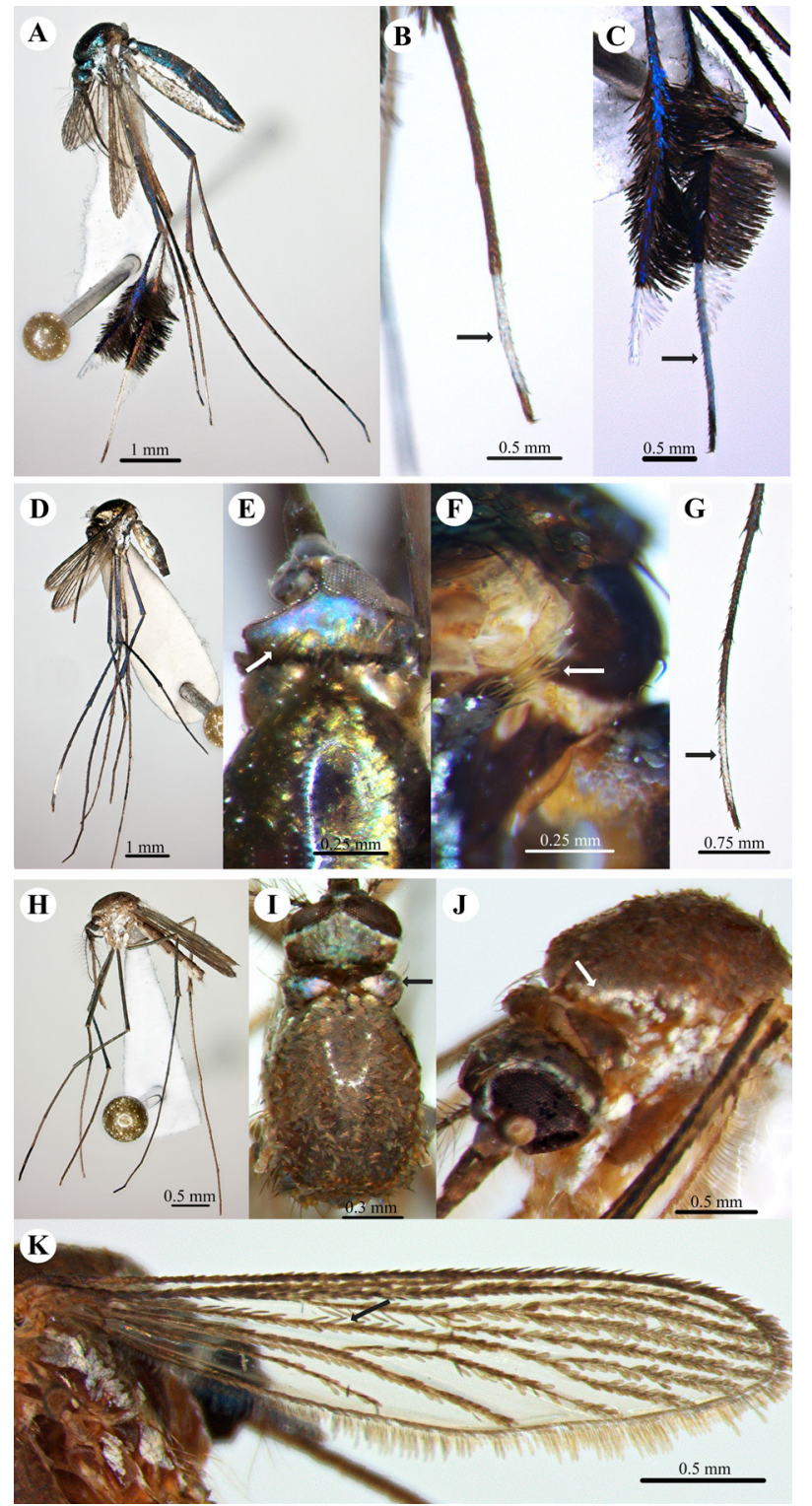

Figures 3. A-C. Sabethes (Sabethes) shannoni: (A) lateral view; (B) Foretarsus with white scales on apex of tarsomere (Ta) II to base of Ta-IV; (C) Midtarsus with white scales on the base of Ta-II to the apex of Ta-IV. D-G. Sabethes (Sabethoides) conditus: (D) lateral view; (E) ociput with golden-green scales; (F) short upper mesepimeral setae, reaching the mesopostnotum; (G) midtarsus covered with white scales on the anterior surface of Ta-II to Ta-IV. H-K. Wyeomyia occulta: (H) lateral view; (I) dorsal view, with pronotal lobes covered with dark scales with violet reflexes; $(\mathbf{J})$ pronotum covered with white scales; (K) wing with the base of vein $\mathrm{M}$ covered by long and large scales.

is covered with white scales on the anterior surface of Ta-II to Ta-IV (Fig. 3G).

Wyeomyia (uncertain subgenus) occulta (BonneWepster \& Bonne, 1919)

Figures 2A, 3H-K

Distribution. Argentina, Bolivia, Brazil, Ecuador, French Guiana, Guyana, Suriname.

New records. Brazil: Paraná: Guaraqueçaba, Tagaçaba (251'19" S, 048 $27^{\circ} 27^{\prime \prime}$ W, 16 m a.s.1.); col. 08.VI.2004,
SO 09h40-12h20, 2 ㅇ (DZUP 343604, DZUP417174);c. 15.X.2004, SO 09h00-14h40, 8 (DZUP 417170, 417171, 417172, 417173, 417174, 417181, 417182, 417183, 417189). Brazil: Paraná: Três Barras do Paraná, Parque Estadual do Rio Guarani (2526'22" S, $053^{\circ} 09^{\prime} 34^{\prime \prime}$ W, $491 \mathrm{~m}$ a.s.1.); col. 23.XI.2004, SO 10h00-11h40, 2 ㅇ (DZUP 343599, DZUP 343649). Brazil: Paraná: Jaguariaíva, Patrimônio Bom Sucesso (2422'44" S, 049³9'38" W, 850 m a.s.1.); col. 10.III.2005, SO 12h40-13h00, 1 우 (DZUP 343543). Brazil: Paraná: Mariópolis, Linha São Pedro (26 $16^{\prime} 50^{\prime \prime} \mathrm{S}, 052^{\circ} 33^{\prime} 53^{\prime \prime} \mathrm{W}, 853 \mathrm{~m}$ a.s.1.); col. 03.III.2005, SO 13h20-13h40, 1q; col. 12.V.2005, SO 10h40-11h40, 1 ㅇ (DZUP 343606).

Bionomic data. This species is widely distributed in Paraná, occurring in the Serra do Mar and Segundo and Terceiro Planalto Paranaense and covering 4 different landscape features: Dense Ombrophilous Forest (coastal), Campos Gerais, Mixed Ombrophilous Forest Temperate zone and Seasonal Semideciduous Forest. At the Paraná coast, this species was collected in the hydrographic basin of the Laranjeiras Bay, while in the rest of the state it was found in the Itararé, Cinzas, Laranjinha and Iguaçu river valleys, which are part of the basin of the Paraná River. On the coast, the air temperature ranges between $19{ }^{\circ} \mathrm{C}$ and $20{ }^{\circ} \mathrm{C}$ and the amount of rainfall ranges between $2,000 \mathrm{~mm}$ and 3,000 $\mathrm{mm}$ annually. In the areas of the subtropical zone the average annual air temperature varies between $19^{\circ} \mathrm{C}$ and $21^{\circ} \mathrm{C}$, while in the forest it rangesbetween $17^{\circ} \mathrm{C}$ and $18^{\circ} \mathrm{C}$. In these regions, the average rainfall ranges from $1,100 \mathrm{~mm}$ to $1,800 \mathrm{~mm}$ annually. In the temperate zone, the average air temperatures are lower, between $15^{\circ} \mathrm{C}$ and $16^{\circ} \mathrm{C}$, with rainfall of $1,800 \mathrm{~mm}$ to $2,000 \mathrm{~mm}$ annually.

Identification. Wy. occulta is characterized by the pronotal lobes covered with dark scales with violet reflexes (Fig. 3I) and the wing with the base of vein M covered by long and large scales (Fig. 3K). It differs from Wy. (Hys.) autocratica Dyar \& Knab, 1906 by having the pronotum covered with white scales (Fig. 3J).

\section{Wyeomyia (Wyeomyia) scotinomus (Dyar \& Knab, 1907)}

Figures 2A, 4A-C

Distribution. Argentina, Brazil, Colombia, Costa Rica, Ecuador, Guyana, Nicaragua, Panama, Paraguay, Trinidad and Tobago.

New records. Brazil: Paraná: Foz do Iguaçu, Fazenda Keller (25 $36^{\prime} 26^{\prime \prime} \mathrm{S}, 054^{\circ} 28^{\prime} 49^{\prime \prime} \mathrm{W}, 228 \mathrm{~m}$ a.s.1.); col. 21.II.2005, SO 15h00-16h00, 2 9 (DZUP 343530, DZUP 343562). Brazil: Paraná: Porto Rico, Ilha Mutum, Parque Nacional de Ilha Grande $\left(22^{\circ} 45^{\prime} 35^{\prime \prime}\right.$ S, $053^{\circ} 16^{\prime} 08^{\prime \prime}$ W, 241 $\mathrm{m}$ a.s.1.); col. 22.III.2004, CO 10h00-11h00, 1 + (DZUP 343564); col. 12.IV.2004, SO 10h20-10h40, 1 ㅇ (DZUP 343567); col. 13.IV.2004, CO 13h00-14h00, 1 ㅇ (DZUP 343565); col. 17.V.2004, SO 11h00-12h00, 1 + (DZUP 343568). Brazil: Paraná: Três Barras do Paraná, Parque 
Estadual do Rio Guarani $\left(25^{\circ} 26^{\prime} 22^{\prime \prime} \mathrm{S}, 053^{\circ} 09^{\prime} 34^{\prime \prime} \mathrm{W}\right.$, $491 \mathrm{~m}$ a.s.1.); col. 10.V.2005, SO 14h40-15h00, 1 q (DZUP 343602).

Bionomic data. This species was detected in the Segundo and Terceiro Planalto Paranaense, where it occurred in Seasonal Semidecidual Forest of humid tropical and subtropical areas. Populations of this mosquito were observed in secondary forests on islands of the Paraná River, as well as in western and southwestern forests of the state that retain primitive characteristics, including the presence of bamboo and conifers. In the tropical zone areas, the annual average air temperature ranges between $21{ }^{\circ} \mathrm{C}$ and $22{ }^{\circ} \mathrm{C}$, while in the subtropical zone areas the average annual air temperature varies between $19{ }^{\circ} \mathrm{C}$ and $21^{\circ} \mathrm{C}$. In these regions, the average rainfall ranges from $1,100 \mathrm{~mm}$ to $1,800 \mathrm{~mm}$ annually.

Identification. Wy. (Wye.) scotinomus has the wings with the base of vein $\mathrm{M}$ covered by long and large scales (Fig. 4B) and differs from Wy. (Wye.) nigritubus Galindo, Carpenter \& Trapido, 1951 by having the midtarsus covered with white scales from tarsomere (Ta) II to the base of Ta-V (Fig. 4C).

\section{Wyeomyia (uncertain subgenus) shannoni Lane \& Cerqueira, 1942 \\ Figure $2 \mathrm{~A}$}

Distribution. Brazil, Ecuador, Nicaragua.

New records. Brazil: Paraná: Guaraqueçaba, Tagaçaba (2513'19" S, 048 27'27" W, 16 m a.s.1.); col. 15.X.2004, SO 11h20-11h40, 1q (DZUP 180622).

Bionomic data. This species occurred in typical Atlantic Forest along the coast of Paraná, within the hydrographic basin of Laranjeiras Bay, which flows directly into the Atlantic Ocean. In this region, the average annual air temperature varies between $19{ }^{\circ} \mathrm{C}$ and $20{ }^{\circ} \mathrm{C}$, and the average rainfall is between $2,000 \mathrm{~mm}$ to $3,000 \mathrm{~mm}$.

Identification. Wy. shannoni differs from Wy. knabi Lane \& Cerqueira, 1942 by presenting the foretarsus bearing white scales at one side of tarsomere V (Ta-V) and pronotal lobes covered with scales with intense blue violet reflections.

\section{Wyeomyia (uncertain subgenus) undulata Del Ponte \& Cerqueira, 1938}

Figures 2A, 4D-F

Distribution. Bolivia, Brazil, Colombia, Costa Rica, Ecuador, Nicaragua, Panama, Paraguay.

New records. Brazil: Paraná: Inajá, Fazenda Paranapanema $\left(22^{\circ} 38^{\prime} 10^{\prime \prime} \mathrm{S}, 052^{\circ} 15^{\prime} 16^{\prime \prime} \mathrm{W}, 263 \mathrm{~m}\right.$ a.s.1.); col. 27.IV.2004, SO 10h20-15h00, 10 q (DZUP 343665, 343666, 416737, 416937, 416938, 416951, 416888, 416889, 416890, 417002); col. 07.VII.2004, SO 12h20 12h40, 1 ( (DZUP 344453).

Bionomic data. This species was collected in the Ter-

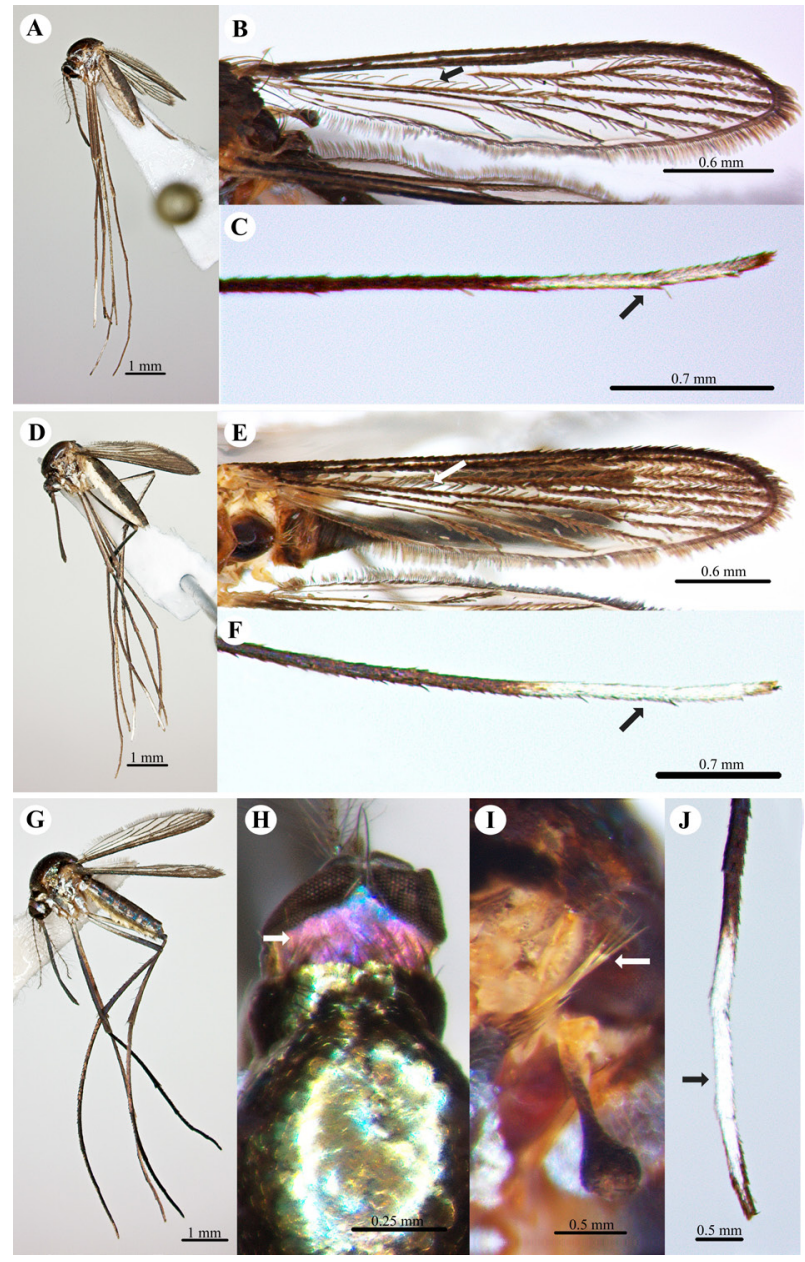

Figures 4. A-C. Wyeomyia (Wyeomyia) scotinomus. (A) lateral view. (B) wing with the base of vein $\mathrm{M}$ covered by long and large scales. (C) midtarsus with white scales from tarsomere (Ta) II to the base of Ta-V. D-F. Wyeomyia undulata. (D) lateral view. (E) wing with the base of vein $\mathrm{M}$ covered by long and large scales. (F) midtarsus with white scales from Ta-Il to the middle of Ta-V. G-J. Sabethes (Sabethoides) glaucodaemon. (G) lateral view. (H) dorsal view, occiput covered with scales with purple reflexes. (I) long upper mesepimeral setae, reaching the mesopostnotum. $(\boldsymbol{J})$ midtarsus with white scales from apex of Ta-II to the base of Ta-V.

ceiro Planalto Paranaense in secondary tropical forest areas along the banks of the Paranapanema River and on islands of the Parana River. In this region, the average annual air temperature is between $21^{\circ} \mathrm{C}$ and $22{ }^{\circ} \mathrm{C}$ and average rainfall varies between $1,100 \mathrm{~mm}$ and $1,600 \mathrm{~mm}$ annually.

Identification. Wy. undulata is very similar to Wy. roucouyana (Bonne-Wepster \& Bonne, 1920) and Wy. chalcocephala Dyar \& Kanb, 1906, but differs by presenting wings with the base of vein $\mathrm{M}$ covered by long and large scales (Fig. 4E) and the midtarsus with white scales from Ta-II to the middle of Ta-V (Fig. 4F).

\section{First records for the state of Paraná}

\section{Sabethes (Peytonulus) whitmani Lane \& Cerqueira,} 1942

Figure 2B 


\section{Distribution. Brazil}

New records. Brazil: Paraná: Paranaguá, Colônia Santa Rita (25³2'49" S, 048 33'50" W, 14 m a.s.1.); col. 21.IX. 2004, SO 12h40-13h00, 1 ㅇ (DZUP 180623).

Bionomic data. This species is found in forest fragments of the coast of Paraná, belonging to the hydrographic basin of Paranaguá Bay. The average annual air temperature ranges from $21^{\circ} \mathrm{C}$ to $22^{\circ} \mathrm{C}$, and the average rainfall varies from $1,800 \mathrm{~mm}$ to $2,000 \mathrm{~mm}$.

Identification. Sa. (Pey.) whitmani differs from Sa. (Pey.) soperi Lane \& Cerqueira, 1942 by having the hindtarsus Ta- 5 entirely covered by dark scales.

\section{Sabethes (Sabethoides) glaucodaemon (Dyar \& Shan-} non, 1925)

Figures 2B, 4G-J

Distribution. Bolivia, Brazil, Guyana, Suriname.

New records. Brazil: Paraná: Porto Rico, Ilha Mutum, Parque Nacional de Ilha Grande (22 $45^{\prime} 35^{\prime \prime}$ S, 053 $16^{\prime} 08^{\prime \prime}$ W, 241 m a.s.1.); col. 22.III.2004, CO 11h00-12h00, 1 ㅇ (DZUP 343668). Brazil: Paraná: Terra Roxa, Fazenda Curupay $\left(24^{\circ} 01^{\prime} 60^{\prime \prime} \mathrm{S}, 054^{\circ} 05^{\prime} 57^{\prime \prime} \mathrm{W}, 244 \mathrm{~m}\right.$ a.s.1.), col. 27.X.2004, CO 07h00-00h00, 7 9 (DZUP 343652, $343656,343663,3343664,343669,343675,344688)$ and col. 25.I.2005, CO 18h00-19h00, 2 ㅇ (DZUP 180507, DZUP 343657). Brazil: Paraná: Maringá, Horto Florestal - Parque do Ingá $\left(23^{\circ} 25^{\prime} 37^{\prime \prime} \mathrm{S}, 051^{\circ} 55^{\prime} 42^{\prime \prime} \mathrm{W}, 543 \mathrm{~m}\right.$ a.s.1.); col. 20.XII.2005, SO 14h20-14h40, 1 ㅇ (DZUP 180508) and CO 14h00-15h00, 19 (DZUP417088).

Bionomic data. This species occurred in the Terceiro Planalto Paranaense in tropical rain forests of the Ivaí river valley, at the mouth of the Piquiri River, and in typical marshland vegetation and flood plains of the Parana River. In these regions, the average annual air temperature ranges from $20{ }^{\circ} \mathrm{C}$ to $22{ }^{\circ} \mathrm{C}$, and average rainfall varies from $1,100 \mathrm{~mm}$ to $1,800 \mathrm{~mm}$.

Identification. $\mathrm{Sa}$. (Sbo.) glaucodaemon is very similar to Sa. (Sbo.) tridentatus and Sa. (Sbo.) chloropterus but differs by having the occiput covered with scales with purple reflexes (Fig. 4H), long upper mesepimeral setae, reaching the mesopostnotum (Fig. 4I), and midtarsus with white scales from apex of Ta-II to the base of Ta-V (Fig. 4J).

\section{Sabethes (Sabethoides) tridentatus Cerqueira, 1961 Figures 2B, 5A-D}

\section{Distribution. Brazil.}

New records. Brazil: Paraná: Foz do Iguaçu, Fazenda Keller (2536'26" S, 054'28'49" W, 228 m a.s.1.); col. 15.III.2004, CO 13h00-16h00, 4ㅇ (DZUP 180519, 180520, 180523, 180524), CO 08h00-11h00, 2 (DZUP 180521, DZUP 180522) and SO 15h00-16h00, 1 ( (DZUP 180511); col. 13.VII.2004, SO 09h40-11h20, 1 q(DZUP 180518). Brazil: Paraná: Cornélio Procópio, Parque Estadual Mata São

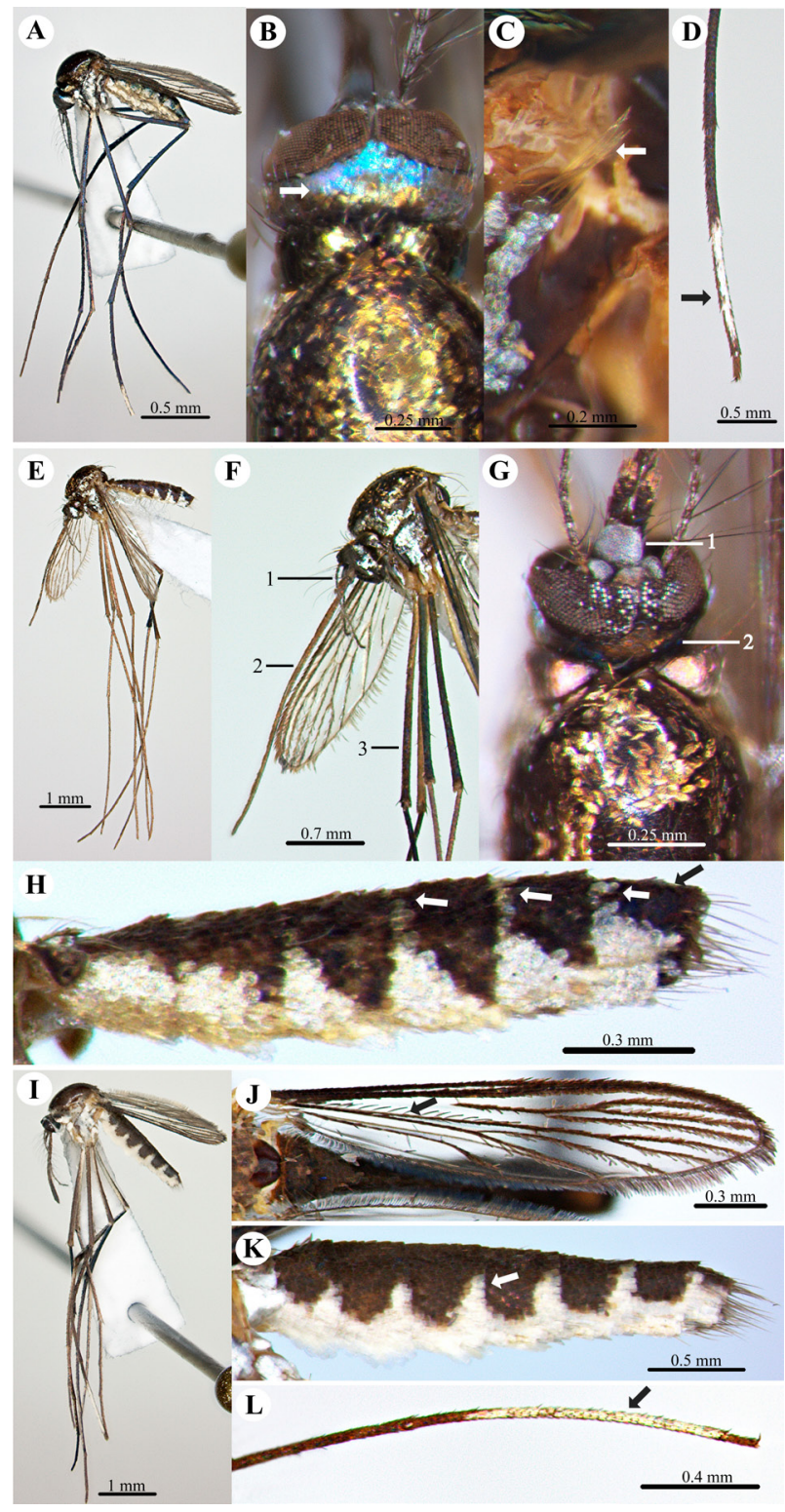

Figures 5. A- D. Sabethes (Sabethoides) tridentatus. (A) lateral view. (B) dorsal view, occiput covered with scales with bluish green reflexes. (C) long upper mesepimeral setae, reaching the mesopostnotum. (D) midtarsus with white scales from apex of tarsomere (Ta) II to the base of Ta-V. E- H. Wyeomeyia (Phoniomyia) fuscipes. (E) lateral view. (F) antenna (1) shorter than proboscis (2) and proboscis longer than anterior femur (3). (G) clypeus (1) without scales; and occiput (2) pronotal lobes covered with scales with purple-green reflexes. (H) abdomen lateral view, with presence of apical white scales from tergite V to VII (white arrows) and absence on tergite VIII (white arrow). I-L. Wyeomyia serratoria. (I) lateral view. (J) wing with the base of vein $M$ covered by long and large scales. (K) abdomen lateral view, with presence of basal white scales from tergite II to VII (white arrows) (L) midtarsus with white scales from apex of tarsomere (Ta) II to the base of Ta-V.

Francisco (2309'03" S, 050 $34^{\circ} 18^{\prime \prime} \mathrm{W}, 553 \mathrm{~m}$ a.s.1.); col. 21.II.2005, SO 14h40-15h00, 1 (DZUP 180509) and CO 14h00-15h00, 1 ㅇ (DZUP 180510). Brazil: Paraná: Terra

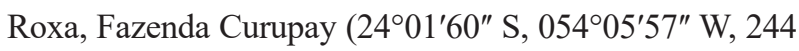
$\mathrm{m}$ a.s.1.); col. 22.VI.2004, CO 11h00-12h00, 1 ㅇ (DZUP 180512); col. 13.XII.2004, SO 15h20-18h00, 4 ㅇ (DZUP 343650, 343651, 343653, 343655), col. 16.XII.2004, 
SO 10h40-11h00, 1 ( (DZUP 343662). Brazil: Paraná: Inajá, Fazenda Paranapanema $\left(22^{\circ} 38^{\prime} 10^{\prime \prime} \mathrm{S}, 052^{\circ} 15^{\prime} 16^{\prime \prime}\right.$ W, 263 m a.s.1.); col. 07.VII.2004, CO 11h40-15h00, 1 ㅇ (DZUP416862); col. 01.III.2005, SO 10h40-15h00, 2 ㅇ (DZUP416868, DZUP416984). Brazil: Paraná: Matinhos,

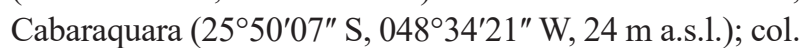
19.X.2004, SO 11h00-12h40, 1 9 (DZUP 180517) and SO 11h40-12h00, 1 q (DZUP 180514). Brazil: Paraná: Guaraqueçaba, Tagaçaba $\left(25^{\circ} 13^{\prime} 19^{\prime \prime}\right.$ S, 048 $27^{\prime} 27^{\prime \prime}$ W, $16 \mathrm{~m}$ a.s.1.); col. 15.X.2004, SO 09h00-11h20, 1 ㅇ (DZUP417169) and SO 10h00-10h20, 1ㅇ (DZUP 180515). Brazil: Paraná: Prudentópolis, Fazenda Álamo

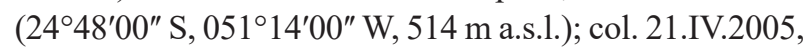
CO 12h00-15h00, 2 ( (DZUP 180525, DZUP417094). Brazil: Paraná: Cianorte, Companhia Melhoramento Norte do Paraná (2339'26" S, 053³7'01" W, 511 m a.s.1.); col. 11.II.2005, SO 11h00-11h20, 19 (DZUP 180513). Brazil: Paraná: Carlópolis and Joaquim Távora, Fazenda Capela (2330'36" S, 04948'59" W, 693 m a.s.1.); col. 23.II.2006, SO 10h00-10h20, 1 + (DZUP 180516).

Bionomic data. This species is widely distributed in Paraná, where it occurs along the coast and in Serra do Mar, Segundo and Terceiro Planalto Paranaense. Within this range, this species was observed in 4 different landscapes: Dense Ombrophilous Tropical and Subtropical forests, Mixed Temperate Ombrophilous Forest and Semidecidual Seasonal Forest. On the coast this species was collected in the hydrographic basin of Laranjeiras Bay and in areas where streams flow directly into the Atlantic Ocean. In the interior, however, it was found in the valleys of the Itararé, Cinzas, Laranjinha, Ivaí, Piquiri Iguaçu and Paraná rivers, which are part of the Paraná river basin. In the coastal region, the air temperature ranges between $19^{\circ} \mathrm{C}$ and $22^{\circ} \mathrm{C}$ and rainfall ranges between $1,800 \mathrm{~mm}$ and 3,000 $\mathrm{mm}$ annually. In the subtropical zone, the average annual air temperature varies between $19^{\circ} \mathrm{C}$ and $22^{\circ} \mathrm{C}$, while the average rainfall ranges from $1,100 \mathrm{~mm}$ to $1,800 \mathrm{~mm}$. In the temperate zone the average temperature of the air is lower, between $16^{\circ} \mathrm{C}$ and $17^{\circ} \mathrm{C}$, with rainfall between $1,600 \mathrm{~mm}$ and $1,800 \mathrm{~mm}$.

Identification. $\mathrm{Sa}$. (Sab.) tridentatus differs from $\mathrm{Sa}$. (Sbo.) glaucodaemon and Sa. (Sbo.) chloropterus by presenting an occiput covered with scales with bluish green reflexes (Fig. 5B), long upper mesepimeral setae, reaching the mesopostnotum (Fig. 5C) and a midtarsus with white scales from apex of tarsomere (Ta) II to the base of Ta-V (Fig 5D).

\section{Wyeomyia (Miamyia) sabethea Lane \& Cerqueira, 1942}

Figure 2B

Distribution. Argentina and Brazil.

New records. Brazil: Paraná: Mariópolis, Linha São Pedro (26 $19^{\prime} 50^{\prime \prime} \mathrm{S}, 052^{\circ} 33^{\prime} 53^{\prime \prime} \mathrm{W}, 853 \mathrm{~m}$ a.s.1.); col. 12.VIII.2004, SO 14h00-14h20, 1 ㅇ.
Bionomic data. This species occurs in the Terceiro Planalto Paranaense in gallery forests found along the Iguaçu river basin where the average annual air temperature ranges from $15{ }^{\circ} \mathrm{C}$ to $16{ }^{\circ} \mathrm{C}$, and the average rainfall is $1,800 \mathrm{~mm}$ to $2,000 \mathrm{~mm}$ per year.

Identification. Wy. (Mia.) sabethea is differentiated from other species by having wings with the base of vein $M$ covered by narrow scales, the tergite bearing small basal white scales, and maxillary palpi with 3 times the size of the proboscis.

\section{Wyeomyia (Phoniomyia) fuscipes (Edwards, 1922)}

Figures 2B, 5E-H

\section{Distribution. Brazil and Paraguay.}

New records. Brazil: Paraná: Piên, Boa Vista $\left(26^{\circ} 06^{\prime} 45^{\prime \prime}\right.$ S, 049²3'14" W, $870 \mathrm{~m}$ a.s.1.); col. 05.V.2005, SO 12h20-12h40, 1 (DZUP 180497).

Bionomic data. This species was found in the Primeiro Planalto Paranaense, where it occurred in forested portions of Araucaria in the Iguaçu river basin. In this area the average annual air temperature ranges from $14^{\circ} \mathrm{C}$ to $15^{\circ} \mathrm{C}$, and average rainfall ranges from $1,600 \mathrm{~mm}$ to $1,800 \mathrm{~mm}$.

Identification. Wy. (Pho.) fuscipes is characterized by antenna shorter than proboscis and proboscis longer than anterior femur (Fig. 5F). This species also differs from other species by having the clypeus without scales, the occiput pronotal lobes covered with scales with purplegreen reflexes (Fig. 5G), and the abdomen with apical white scales from tergite V to VII and absence on tergite VIII (Fig. 5H).

\section{Wyeomyia (uncertain subgenus) serratoria (Dyar \& Nuñez Tovar, 1927) \\ Figures 2B, 5I-L}

Distribution. Argentina, Brazil, Colombia e Venezuela.

New records. Brazil: Paraná: Foz do Iguaçu, Fazenda Keller (25 36'26" S, 054 $28^{\circ} 48^{\prime \prime} \mathrm{W}, 228 \mathrm{~m}$ a.s.1.); col. 15.IX.2004, SO 10h00-11h00, 1q (DZUP 180499). Brazil: Paraná: Porto Rico, Ilha Mutum, Parque Nacional de Ilha Grande $\left(22^{\circ} 45^{\prime} 34^{\prime \prime} \mathrm{S}, 053^{\circ} 16^{\prime} 08^{\prime \prime} \mathrm{W}, 241 \mathrm{~m}\right.$ a.s.1.); col. 23.III.2004, SO 14h00-15h00, 1 \% (DZUP 180500). Brazil: Paraná: Três Barras do Paraná, Parque Estadual do Rio Guarani $\left(25^{\circ} 26^{\prime} 22^{\prime \prime} \mathrm{S}, 053^{\circ} 09^{\prime} 34^{\prime \prime} \mathrm{W}\right.$, $491 \mathrm{~m}$ a.s.1.); col. 23.XI.2004, SO 11h20-13h20, 29; CO 10h00-11h00, 1 q (DZUP 343659); col. 01.III.2005, SO 12h00-15h00, 4ㅇ (DZUP 180502, 343667, 343672, 343673); col. 10.V.2005, SO 10h40-11h00, 2 ㅇ (DZUP 343661, DZUP 343670).

Bionomic data. This species was found coexisting with Wy. (Wyo.) scotinomus in areas of seasonal semidecidual forest of the tropical and humid subtropical zones of the Segundo and Terceiro Planalto Paranaense. It occurred on the islands of the Paraná River and along the Iguaçu River in portions of remnant and secondary forests. In the 
areas at the tropical zone the annual average air temperature ranges between $21^{\circ} \mathrm{C}$ and $22{ }^{\circ} \mathrm{C}$, while in the areas of subtropical zone the average annual air temperature varies between $19{ }^{\circ} \mathrm{C}$ and $21^{\circ} \mathrm{C}$. In these regions the average rainfall ranges from $1,100 \mathrm{~mm}$ to $1,800 \mathrm{~mm}$.

Identification. Wy. serratoria is characterized by wings with the base of vein M covered by long and large scales (Fig. 5J), abdomen with basal white scales from tergite II to VII (Fig. 5K) and midtarsus with white scales from apex of tarsomere (Ta) II to the base of Ta-V (Fig. 5L).

\section{Discussion}

New records of Sabethini have been found for southern Brazil and the state of Paraná. With 2 exceptions noted below, the occurrence of most species of the tribe is best known for the Amazon region. Wy. shannoni and Wy. undulata had been previously recorded in state of Rio de Janeiro (Lane and Cerqueira 1957, Guimarães and Arlé 1984). Consequently, the records of the other species in the Atlantic Forest biome and the southernmost records of South America are new. Among the reported species, Wy. (Wyo.) scotinomus was previously only known from Central America (Costa Rica, Panama), the Caribbean island of Trinidad, and South America (Brazil, Colombia and Ecuador) (WRBU 2017, Navarro et al. 2015).

The other species of Sabethini are distributed in various states of the Amazon, for example $S a$. (Sab.) shannoni, described from specimens collected in the Amazon, and Sa. (Sbo.) conditus from Rondônia (Cerqueira 1961, Moses et al. 2000). Similarly, Wy. shannoni and Wy. undulata were also described from specimens collected in Acre and Mato Grosso, respectively, and Wy. occulta has been reported as occurring in the state of Pará (Lane and Cerqueira 1957, Del Ponte and Cerqueira 1938).

Based on current observations, Wy. (Wyo.) scotinomus and Wy. occulta are now known to occur at the Iguaçu river valley, which is their southernmost record (latitude $25^{\circ}$ and $26^{\circ}$, respectively). Additionally, $\mathrm{Sa}$. (Sab.) shannoni and Wy. undulata were collected in the Paranapanema river valley (latitudes $23^{\circ}$ and $22^{\circ}$, respectively), and $\mathrm{Sa}$. (Sbo.) conditus in the Tibagi river valley (latitude $23^{\circ}$ ) were collected in northern Paraná. The record of $W y$. shannoni on the coast of Paraná in Brazil expands its geographical distribution further south of previous records from areas of dense forest in the coastal states of Rio de Janeiro and São Paulo (Guimarães et al. 1989, 2000).

The first records of Sabethini for the state of Paraná had been previously found in southern Brazil. Sabethes (Pey.) whitmani, Wy. (Pho.) fuscipes and Wy. (Mia.) sabethea (Paterno \& Marcondes 2004, Reis et al. 2010, Santos et al. 2014) had been previously found in the state of Santa Catarina; and Sa. (Pey.) whitmani (=morphotype whitmani/identicus), Sa. (Sbo.) tridentatus, Wy. serratoria and Sa. (Sbo.) glaucodaemon had been previously found in Rio Grande do Sul (Cardoso et al. 2005, Gomes et al. 2010).
Although researchers are still not sure whether Sabethini mosquitoes can transmit infectious agents to humans, their epidemiological importance is notorious, as they have been found naturally infected with arboviruses (Shope et al. 1961, Hervé et al. 1986). Their potential role in the natural cycle of arboviruses instigates us to try to understand how the transmission of these virus occur in the forest environment and whether it can affect humans. The answer to these questions is dependent on new studies on the behavior these mosquitoes in their natural environment, including isolated relict species in areas of remnant forests.

\section{Acknowledgements}

We thank Dr Natal Jataí de Camargo and his team from Secretaria de Estado da Saúde do Paraná for making this study possible, Prof. Dr Maria Anice Mureb Sallum for confirming our identifications of the specimens, and Kirsten Smith for the revision of the English version of the manuscript.

\section{Authors' Contributions}

AMS developed the research project that resulted in the article. AMS identified the specimens. DRS, ECC, ACF and CP participated in the collection of specimens. AMS and BWF developed the distribution map. BWF photographed and edited the images. AMS wrote the text and AMS, DRS, ECC, ACF, CP, BWF and MANS read, made suggestions and accepted the last version of the manuscript.

\section{References}

Anjos AF, Navarro-Silva MA (2008) Culicidae (Insecta: Diptera) em área de Floresta Atlântica, no Estado do Paraná, Brasil. Acta Scientiarum. Biological Sciences 30 (1): 23-27. https://doi.org/10.4025/ actascibiolsci.v30i1.1411

Bona ACD, Navarro-Silva MA (2008) Diversidade de Culicidae durante os períodos crepusculares em bioma de Floresta Atlântica e paridade de Anopheles cruzii (Diptera: Culicidae). Revista Brasileira Zoologia 25 (1): 40-48. https://doi.org/10.1590/S010181752008000100007

Cardoso JC, Paula MB, Fernandes A, Santos E, Almeida MAB, Fonseca DF, Sallum MAM (2010) Novos registros e potencial epidemiológico de algumas espécies de mosquitos (Diptera, Culicidae), no estado do Rio Grande do Sul. Revista da Sociedade Brasileira de Medicina Tropical 43 (5): 552-556. https://doi.org/10.1590/S003786822010000500016

Cardoso JDC, Corseuil E, Barata JMS (2005) Culicinae (Diptera, culicidae) occurring in the State of Rio Grande do Sul, Brazil. Revista Brasileira de Entomologia 49 (2): 275-287. https://doi. org/10.1590/S0085-56262005000200013

Cerqueira NL (1961) Distribuição geográfica dos mosquitos da Amazônia (Diptera, Culicidae, Culicinae). Revista Brasileira de Entomologia 10: 111-168.

Del Ponte E, Cerqueira N (1938) Alguns sabethineos do Brasil (Diptera, Culicidae). Revista de Entomologia 8: 225-237.

Favretto MA, Santos EB, Geuster CJ (2013) Entomofauna do Oeste do Estado de Santa Catarina, Sul do Brasil. EntomoBrasilis 6 (1): 42-63. https://doi.org/10.12741/ebrasilis.v6i1.271

Ferreira-de-Freitas V, França RM, Bartholomay LC, Marcondes CB 
(2016) Contribution to the biodiversity assessment of mosquitoes (Diptera: Culicidae) in the Atlantic Forest in Santa Catarina, Brazil. Journal of Medical Entomology 23: 1-9. https://doi.org/ 10.1093/jme/tjw196

Forattini OP (2002) Culicidologia Médica, Vol. 2: Identificação, Biologia, Epidemiologia. Editora da Universidade de São Paulo 864 p.

Gomes AC, Paula MB, Vitor Neto, JB, Borsari R, Ferraudo AS (2009) Culicidae (Diptera) in the dam area bordering the states of Santa Catarina and Rio Grande do Sul, Brazil. Neotropical Entomology 38 (4): 553-555. https://doi.org/10.1590/S1519-566X2009000400021

Gomes ADC, Torres MAN, Paula MBD, Fernandes A, Marassá AM, Consales CA, Fonseca DF (2010) Ecologia de Haemagogus e Sabethes (Diptera: Culicidae) em áreas epizoóticas do vírus da febre amarela, Rio Grande do Sul, Brasil. Epidemiologia e Serviços de Saúde 19 (2): 101-113. https://doi.org/10.5123/S1679-4974201 0000200003

Guedes MLP, Navarro-Silva MA (2014) Mosquito community composition in dynamic landscapes from the Atlantic Forest biome (Diptera, Culicidae). Revista Brasileira de Entomologia 58 (1): 88-94. https://doi.org/10.1590/S0085-56262014000100014

Guimarães AE, Arlé M (1984) Mosquitos no Parque Nacional da Serra dos Órgãos, Estado do Rio de Janeiro, Brasil. I - Distribuição estacional. Memórias do Instituto Oswaldo Cruz 79: 309-23. https:// doi.org/10.1590/S0074-02761984000300004

Guimarães AE, Gentile C, Lopes CM, Mello RPD (2000) Ecology of mosquitoes (Diptera: Culicidae) in areas of Serra do Mar State Park, State of São Paulo, Brazil. II-Habitat distribution. Memórias do Instituto Oswaldo Cruz 95 (1): 17-28. https://doi.org/10.1590/ S0074-02762000000100002

Guimarães AE, Motta MA, Arlé M, Machado RM, Gonçalves LD (1989) Bionomia de mosquitos (Diptera: Culicidae) em areas da mata atlantica no municipio de Itaguai, estado do Rio de Janeiro, Brasil. I Frequencia intra, peri e extradomiciliar. Memórias do Instituto Oswaldo Cruz 84 (4): 243-254. https://doi.org/10.1590/ S0074-02761989000800044

Harbach RE (2018) [Sabethini] Mosquito Taxonomic Inventory. http:// mosquito-taxonomic-inventory.info/. Accessed on: 2018-02-11.

Harbach RE, Huong VD, Kitching IJ (2007) Systematics of Kimia, a new genus of Sabethini (Diptera: Culicidae) in the oriental region. Proceedings of the Entomological Society of Washington 109 (1) 102-120.

Hervé JP, Dégallier N, Travassos da Rosa APA, Pinheiro FP, Sá Filho GC (1986) Aspectos ecológicos das arboviroses. Instituto Evandro Chagas: 50 anos de Contribuição às Ciências Biológicas e à Medicina Tropical 1: 409-437.

Hutchings RSG, Sallum MAM, Ferreira RLM, Hutchings RW (2005) O acervo de mosquitos (Diptera, Culicidae) de Nelson L. Cerqueira na Coleção de Invertebrados do Instituto Nacional de Pesquisas da Amazônia, Manaus, Brasil. Revista Brasileira de Entomologia 49 (1): 15-28. https://doi.org/10.1590/S0085-56262005000100004

Kronen M (1990) A erosão do solo de 1952 a 1985 e seu controle no Paraná. Translated by: Popper I; Bach A. M. Londrina: IAPAR, (IAPAR. Boletim Técnico, 30).

Lane J (1953) Neotropical Culicidae, São Paulo, Brazil, 1112 pp.

Lane J, Cerqueira NL (1942) Os sabetíneos da América (Diptera, Culicidae). Arquivos de Zoologia do Estado de São Paulo 3 (9): 473-849.

Lane J, Cerqueira NL (1957) The validity and change of name of two species of Wyeomyia (Diptera, Culicidae). Proceedings of the Entomological Society of Washington 59: 244

Lopes J, Santos FP, Martins EAC, Pereira PAC, Oliveira JE, Oliveira O, Oliveira Neto BP, Nunes V, Zequi JAC (2014) Fauna Culicidae (Diptera) em depressões de Rochas da margem de um Ribeirão no Norte do Paraná. Revista Brasileira de Zoociências, 14 (1, 2, 3) 27-33.

Maack R (1981) Geografia física do Estado do Paraná. 2a ed. Rio de Janeiro: J. Olympio, 450 p.
Marchi MJ, Müller GA, Marcondes CB (2010) Mosquitos (Diptera: Culicidae) de uma futura Unidade de Conservação em área de Mata Atlântica no Sul do Brasil. EntomoBrasilis 3 (2): 34-37.

Marchon-Silva V, Lourenço-de-Oliveira R, Almeida MDD, SilvaVasconcelos AD, Costa J (1996) The type specimens of mosquitoes (Diptera, Culicidae) deposited in the entomological collection of the Instituto Oswaldo Cruz, Rio de Janeiro, Brazil. Memórias do Instituto Oswaldo Cruz 91 (4): 471-478. https://doi.org/10.1590/ S0074-02761996000400014

Moses DA, Howard TM, Harbach RE (2000) A new species of the subgenus Sabethoides of Sabethes (Diptera: Culicidae) from Venezuela and Brazil. Proceedings of the Entomological Society of Washington 102 (4): 991-1002.

Motta MA, Lourenço-de-Oliveira R, Sallum MAM (2007) Phylogeny of genus Wyeomyia (Diptera: Culicidae) inferred from morphological and allozyme data. The Canadian Entomologist 139 (05): 591-627. https://doi.org/10.4039/n06-088

Morellato LPC, Haddad CFB (2000) The Brazilian Atlantic Forest Biotropica 32: 786-792. https://doi.org/10.1111/j.1744-7429.2000. tb00618.x

Müller GA, Bona ACD, Marcondes CB, Navarro-Silva MA (2012) Crepuscular activity of culicids (Diptera, Culicidae) in the peridomicile and in the remaining riparian forest in Tibagi River, state of Paraná, Brazil. Revista Brasileira de Entomologia 56 (1): 111-114. https://oi.org/10.1590/S0085-56262012005000006

Müller GA, Dalavequia MA, Wagner G, Marcondes CB (2014) Blood sucking Diptera (Culicidae, Psychodidae, Simuliidae) in forest fragment under impact of dam in the borderland of Rio Grande do Sul and Santa Catarina states, Brazil. Ciência Rural 44 (7): 1194-1196. https://doi.org/10.1590/0103-8478cr20131656

Müller GA, Kuwabara EF, Duque JE, Navarro-Silva MA, Marcondes CB (2008) New records of mosquito species (Diptera: Culicidae) for Santa Catarina and Paraná (Brazil). Biota Neotropica 8 (4): 211-218. https://doi.org/10.1590/S1676-06032008000400021

Navarro JC, Enríquez S, Duque P, Campaña Y, Benítez Ortíz W (2015) New mosquito species records for Ecuador, from Pululahua volcano (Andes) and Napo province (Amazon). Journal of Entomology and Zoology Studies 3 (6): 392-396.

Paterno U, Marcondes CB (2004) Mosquitoes with morning biting activity in the Atlantic forest, Brazil (Diptera, Culicidae). Revista de Saúde Pública 38 (1): 133-135. https://doi.org/10.1590/S003489102004000100019

Reinert JF (2009) List of abbreviations for currently valid generic-level taxa in family Culicidae (Diptera). European Mosquito Bulletin 27: 68-76.

Reis M, Müller GA, Marcondes CB (2013) Inventário de mosquitos (Diptera: Culicidae) da Unidade de Conservação Ambiental Desterro, Ilha de Santa Catarina, Sul do Brasil. Biota Neotropical 10 (3): 333-337. https://doi.org/10.1590/S1676-06032010000300031

Santos EB, Muller GA, Favretto MA (2014) Mosquitos (Diptera: Culicidae) do Parque Natural Municipal do Vale do Rio do Peixe, Joaçaba, Santa Catarina, Brasil, com novos registros para o estado. Evidência-Ciência e Biotecnologia 14 (1): 21-34.

Shope RE, Causey CE, Causey OR (1961) Itaqui Virus, a New Member of Arthropod-Borne Group C. American Journal of Tropical Medicine and Hygiene 10 (2): 264-265. https://doi.org/10.4269/ ajtmh.1961.10.264

Tissot AC, Navarro-Silva MA (2008) Lista das espécies de Culicidae (Diptera) depositadas na Coleção de Entomologia Pe. J. S. Moure. Revista Brasileira de Entomologia 52 (2): 263-268. https://doi. org/10.1590/S0085-56262008000200004

Wons I (1985) Geografia do Paraná. Curitiba, Ensino Renovado Editora, $5^{\mathrm{a}}$ ed., $172 \mathrm{p}$

WRBU (2017) Walter Reed Biosystematics Unit - Mosquito classification - online catalog. http://www.mosquitocatalog.org/. Accessed on: $2017-10-17$. 